University for Business and Technology in Kosovo

UBT Knowledge Center

UBT International Conference

2014 UBT International Conference

Nov 8th, 2:00 PM - 2:15 PM

\title{
Challenges of Spatial Planning in Kosovo in Transition Time
}

\author{
Besim Gollopeni \\ University for Business and Technology, besim.gollopeni@gmail.com \\ Alban Kurtishaj \\ University for Business and Technology, albankurtishaj86@gmail.com
}

Follow this and additional works at: https://knowledgecenter.ubt-uni.net/conference

Part of the Architecture Commons

\section{Recommended Citation}

Gollopeni, Besim and Kurtishaj, Alban, "Challenges of Spatial Planning in Kosovo in Transition Time" (2014). UBT International Conference. 5.

https://knowledgecenter.ubt-uni.net/conference/2014/all-events/5

This Event is brought to you for free and open access by the Publication and Journals at UBT Knowledge Center. It has been accepted for inclusion in UBT International Conference by an authorized administrator of UBT Knowledge Center. For more information, please contact knowledge.center@ubt-uni.net. 


\title{
Challenges of Spatial Planning in Kosovo in Transition Time
}

\author{
Besim Gollopeni ${ }^{1}$, Alban Kurtishaj ${ }^{2}$ \\ ${ }^{1}$ University for Business and Technology - UBT \\ ${ }^{2}$ STS "Skender Luarasi" \\ Prishtina, Kosovo \\ besim.gollopeni@gmail.com ${ }^{1}$, albankurtishaj86@gmail.com²
}

\begin{abstract}
Spatial planning refers to the methods used by the public sector to influence the distribution of people and items in the area, always having balanced development in space. Spatial planning for people, land, homes, where we live, learn, heal, work, have fun, public service, and all items have their place. Today, many scientific disciplines are closely related to spatial planning, and through the three main components (social, economic and environmental). In the postmodern time, spatial planning takes place at the local, regional, national, transnational level and often results in the creation of a spatial plan within the state/s. System and spatial planning practices, though vary from one place to another, they have their similarities in content, however, distinguishes the approach and techniques used.

Until 2000, spatial planning in Kosovo is developed at a modest scale, concentrated only in urban areas (cities) and master plans (some regions of the country), in postmodern period (after 2000), the system and practices of spatial planning have made progress in general and especially in drafting national spatial strategies and local development strategies and urban however, there are also disadvantages. In this period, spatial planning, despite the progress, there are still many challenges that face every day and particularly local institutions and thus hinder the lives of citizens. In addition, the lack of human capacity, financial and unwillingness of policy-making and decision-making to address this issue so seriously, in the design and implementation of spatial plans, made uncontrolled developments, take shape across municipalities, causing loss of agricultural land, unplanned development, imbalance, degradation of natural and cultural values, rapid population migrations from the countryside to the city, creating urban chaos and making the citizens' lives more difficult.
\end{abstract}

Keywords: spatial planning, central, local, urban.

\section{Introduction}

If anything is certain, it is that change is certain. The world we are planning for today will not exist in this form tomorrow.- Philip Crosby.

Spatial planning is one of the newest scientific disciplines where as social organized activity presented in the early XX century, and, as an activity carried on in the spontaneously form appears from the moment when human consciousness began to evolve to the settlement where lives and works. Given the highly complex objectives and tasks of spatial planning, as well as close relationship with the large number of scientific disciplines, spatial planning dates from twenties of the XX century, at a time when the society reached a high level of economic and social development.

There are numerous definitions of spatial planning. One of the earliest definitions comes from the European Charter for Regional / Spatial Planning (often called "Torremolinos Charter'), adopted in 1983 by the European Conference of Ministers responsible for Regional Planning (CEMAT):" Regional / Spatial Planning gives geographical expression policies economical, social, cultural and ecological society. It is at the same time a scientific discipline, an administrative technique and a policy developed as an interdisciplinary and comprehensive approach directed towards a balanced regional development and the physical organization of space according to an overall strategy":http://en.wikipedia.org/wiki/Spatial_planning. 
By definition, objectives and tasks of spatial planning clearly seen that it is a scientific discipline that examines which analyzes all the social and natural laws for the exchange of matter between man and space, which is mainly realized through the manufacturing process, as conscious human activity which directly affects the changing nature, owns and adapts to conform to his needs.

Spatial planning is concerned with "the problem of coordination or integration of the spatial dimension of sectoral policies through a territorially-based strategy" (Cullingworth and Nadin, 2006: 91). More complex than simple land-use regulation, it addresses the tensions and contradictions among sectoral policies, for example for conflicts between economic development, environmental and social cohesion policies. The key role of spatial planning is to promote a more rational arrangement of activities and to reconcile competing policy goals. The scope of spatial planning differs greatly from one country to another, but most share a number of similarities. In almost all countries, spatial planning is concerned with identifying long- or medium-term objectives and strategies for territories, dealing with land use and physical development as a distinct sector of government activity, and coordinating sectoral policies such as transport, agriculture and environment (Koresawa and Konvitz, 2001).

In Slovenia, spatial planning is defined in the 2002 Spatial Planning Act as an interdisciplinary activity involving planning land use, determining the conditions for the development and location of activities, identifying measures for improving the existing physical structures and determining the conditions for the location and execution of planned physical structures (Slovenian Ministry of the Environment, Spatial Planning and Energy, 2002).

There are a number of spatial planning systems in the world. Among the most popular systems in Europe, in particular, spatial planning system is of local, regional and national level. Such a system of spatial planning is available in most of the Western Balkan countries except Kosovo where spatial planning system is divided into two levels: a) local level and b) the central level.

Spatial planning as a social activity in Kosovo has its origins after the end of World War II, namely early $60 \mathrm{~s}$. At that time several regional master plans and general urban plans for cities have been developed.

During the 70s, as in many developed countries, powerful socio-economic changes also occurred in Kosovo, which have influenced the spatial / urban planning. As a result of industrial processes, mechanical movements of population from rural to urban area, has brought territorial drastic changes in many developed countries of the world, and in Kosovo such changes, with the large influx of rural to urban population areas occurred in the last decade, respectively after 1999.

In Europe, due to the urgent need to manage changes in concepts and planning strategies are constantly becoming modifications. The most important turnaround that spatial planning awareness is not simply related to the physical separation of land for different uses, but that is the model the spatial manifestation of economic, social, cultural and environmental society (Gollopeni, 2010).

Interdisciplinary approach enables spatial planning work in teams established by different areas profiles, thus enabling cooperation and coordination of activities among them in determining the objectives, strategies, methods and measures for solving the problems faced in planning determining the spatial and territorial development of the guidelines.

Despite progress in the field of spatial planning in Kosovo, yet is left much to be done.

The purpose of this study is to identify achievements in the design of the central and local (MDP \& UDP) plans, current challenges, causes, and at the end to come out with some conclusions and recommendations.

\section{The legal framework of spatial planning in transition period}

The origin of spatial planning in Kosovo dates to the years after World War II, initially being applied to urban areas (cities) and then taking place in smaller urban centers (towns), ie, in the order of 1949 general urban plans. The first institutional initiatives to spatial planning in the former Yugoslavia are also related to the foundation of the Croatian Institute for Urbanism, which established adequate methodology for regional planning.

In 1973 was designed the Spatial Plan for Socialist Autonomous Province of Kosovo, but this plan was not implemented in practice at the appropriate level, due to political developments in the country. During 1990 - 1995 was also designed Serbia Spatial Plan but later (after 2005), which itself included 
the territory of Kosovo, however, this approach of Serbia for Kosovo society and its institutions was absolutely unacceptable the fact that Kosovo has been separated territorially from Serbia (former Yugoslavia) and had its own institutions, and moreover Yugoslavia no longer existed in which were both states (Kosovo and Serbia) and other countries.

In the early $80 \mathrm{~s}$, when the political situation deteriorated, especially during the $90 \mathrm{~s}-$ Kosovo was at war situation, where all around development and spatial planning in the area / city in the country for several decades already had stagnated especially in rural areas. Following the liberation of Kosovo (in '99), started a significant progress especially by drafting the new Law on Spatial Planning 2003/14 and other acts under the law but since the country entered transition stage, it was difficult to monitor developments in space. As a result of the transition period in which the country was going through, uncontrolled developments took place across the territory, causing buildings wild, loss of agricultural land, and unbalanced development in space.

Many countries have recently made fundamental reforms to the body of planning law to enable changes in the elaboration and operation of their planning systems. In some countries, however, planning statutes have not kept pace with the reality of spatial development. The problem is usually not a lack of legislation, but rather that the legislation is no longer relevant.

Reform has happened in Kosovo, with the approval of Law no. 03/106 on the Amendment of the Law on Spatial Plan and coordinate (hereinafter: Law on Planning) and other legal acts in Kosovo, has made a major step to support current trends in the field of spatial planning - the legjislative (Gollopeni, 2013a). According to the Law on Spatial Planning, Kosovo has two levels of spatial planning:

a) Central planning and

b) The local planning;

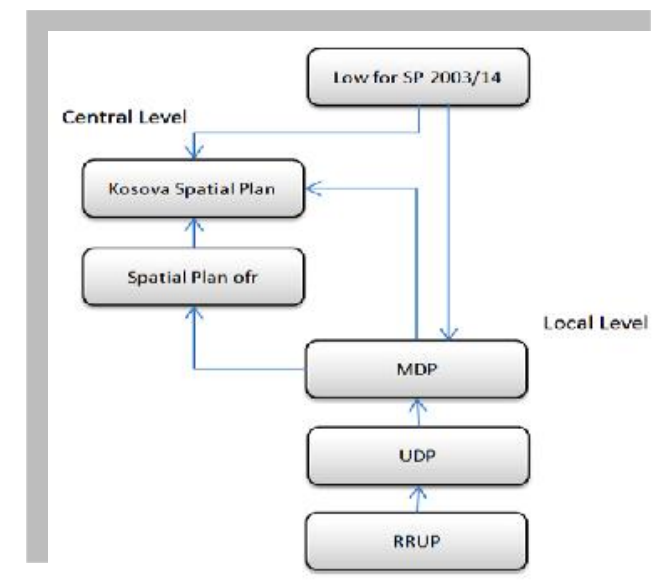

Fig. 1. Hierarchy of spatial planning system in Kosovo under the Law on Spatial Planning Law no. 2003/14 and Law no. 03/106.

At the central level, according to the Planning Law 2003/14, there are two types of spatial planning: a) spatial planning for the entire territory of Kosovo and b) Spatial planning for specific areas. Spatial planning for the entire territory of Kosovo covers the whole country therefore is developed a Draft Spatial Plan as the plan SPK 2010 - 2020+. On the other hand, planning for special areas covers specific areas of importance such as national parks, industrial parks, natural, historic, etc.

Government, namely the Prime Minister's office decides for development of central character plans and the Ministry of Environment and Spatial Planning respectively Spatial Planning Institute is responsible for the design of these plans. After drafting the spatial plan, the Ministry concerned is obliged to send the plan to the government for approval, and then the Government under law sends it for consultations to the National Planning Council, but that the latter, so far at least never happened. The National Planning Council even though established by the Ministry of Environment and Spatial Planning has been non-functional and as such two years ago is cancelled. The government is also obliged under the 
Law (2003/14) to precede the spatial plan in the Kosovo Assembly for approval, and this is the last stage where it then begins the implementation phase of the plan.

At the local (municipal) level, the Law on Spatial Planning is of three planning types including: a) Municipal Development Planning, b) Urban Development Planning and c) Urban Regulatory Planning. Municipal Development Plan covers the entire territory of the municipality, including city and rural areas, while urban development planning includes only urban area (city). While urban regulatory planning (plan) includes part (neighborhood) smaller urban and / or special areas.

For the development of local-level plans, Spatial Planning Law requires, when it comes to the MDP and UDP while, URP are the result of two recent planning, thus municipalities take a decision for drafting. The municipality is also required under the law on spatial planning (2003/14) to establish Spatial Planning Council, whose mission is to provide advices and opinions when drafting the municipal spatial plans. Although all municipalities that have developed relevant spatial planning council established during the development of local spatial plans, practice has shown that this council for planning has been established to meet the legal aspect, but in most cases was not professional in the field of planning.

Kosovo Municipalities when drafting the Municipal Development Plan are required by law 2003/14 to submit MDP to the Ministry of Environment and Spatial Planning to obtain consent, where it is the last stage of completion of the plan and then begins its implementation. UDP and URP adopted by municipalities must be in harmony with the MDP, as well as MDP under the Spatial Plan of Kosovo. Spatial Planning Law (2003/14) guides all spatial plans, starting from the lowest level then regulatory spatial plan, to be in harmony with each other and the Spatial Plan of Kosovo.

Since the declaration of Independence of Kosovo (2008), the need arose to amend / supplement the Law on Spatial Planning 2003/14, as well as for changing many other laws in the country. Law no. 03/106 amending the Law on Spatial Planning no. 2003-14, required also the inclusion of planning to protected areas of cultural heritage in general, out of political agreement (the Ahtisari package). Even the Law was good enough; it was not sufficiently implemented in the field. Therefore, in July 31th, 2013, Kosovo Assembly approved the Law on Spatial Planning (Law no. 04 / L-174). Under this law are again two levels of spatial planning but is only removed urban development plan (UDP), and is added municipal zoning map and zoning map of Kosovo. Zoning map is a reflection of the spatial plan and map showing directions through the development and construction conditions. Zoning maps will be published online on the website of the relevant institution. Zoning map is an advantage because it is easily understandable and accessible to all.

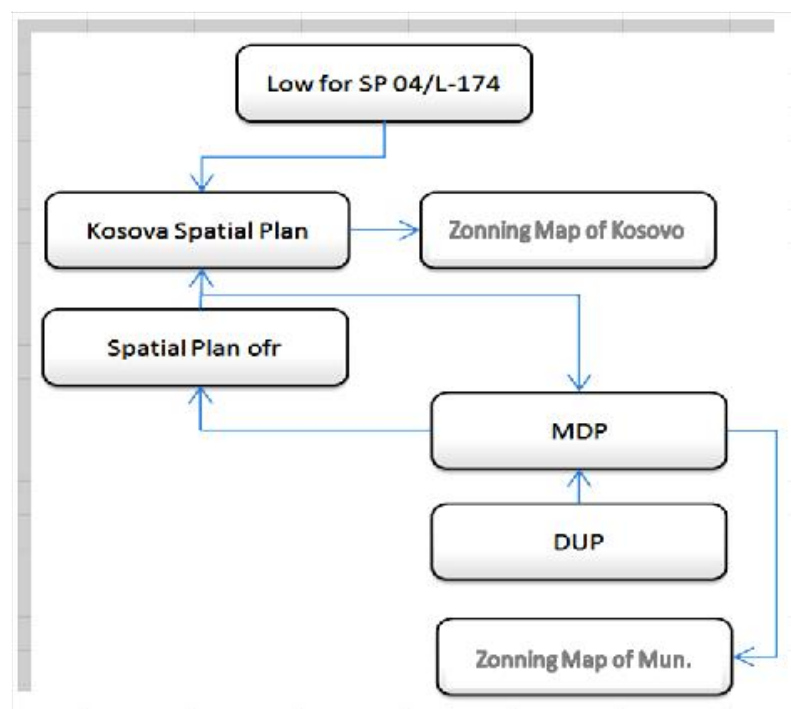

Fig. 2. Hierarchy of spatial planning system in Kosovo under the Law on Spatial Planning Law no. 04 / L-174. 
In other cases, reform in planning law has not been a high priority. In these cases, effective spatial development at all levels has not been implemented yet, as the legal basis has not been put in place to facilitate the planning process. This includes provisions that require cooperation among planning authorities to address sectoral interests to ensure consistency in the decision-making process. Where planning reform has taken place, it is generally targeted at shifting the focus from physical land-use regulation to an integrative spatial planning approach.

\section{The (non) achievements in the field of spatial planning}

Spatial planning has a regulatory and a development function. As a regulatory mechanism, government (at local and/or national level) has to give approval for certain activity; as a development mechanism, government has to elaborate upon development tools for providing services and infrastructure, for establishing directions for urban development, preserving national resources, and establishing incentives for investment, etc.

Spatial planning aims to:

(a) Promote territorial cohesion through a more balanced social and economic development of regions, and improved competitiveness;

(b) Encourage development generated by urban functions and improve the relationship between the town and countryside;

(c) Promote more balanced accessibility;

(d) Develop access to information and knowledge;

(e) Reduce environmental damage;

(f) Enhance and protect natural resources and natural heritage;

(g) Enhance cultural heritage as a factor for development;

(h) Develop energy resources while maintaining safety;

(i) Encourage high-quality, sustainable tourism;

(j) Limit the impact of natural disasters.

Effective spatial planning also helps to avoid the duplication of efforts by actors such as government departments, commercial developers, communities and individuals. This is of great importance, as many of the above issues are of a cross-sectoral nature and therefore should be treated as such. Spatial planning is a public sector activity at all levels. Hence a clear distribution of responsibilities is needed between the different levels of administration.

As in any other country in transition time and so in Kosovo changes in spatial planning system are many challenges related to different natures. Despite progress made in the country, in the legislative, drafting laws and other normative acts, which enable sustainable spatial development and are in line with the spatial policies of developed countries, those EU, however, is an indisputable fact, the lack of implementation at the appropriate level. As a consequence of the latter, unplanned developments have taken shape throughout the country, causing a loss of agricultural land, degradation of urban or cultural - historic heritage, wild constructions in urban, peri-urban, rural, parks national and so on.

Until now, in central level are designed and are in the process of drafting some spatial plans;

\section{Drafted:}

- Spatial Plan of Kosovo 2010 - 2020+;

- Spatial Plan for Special Interest Area "New Mining Field";

- Spatial Plan of Special Interest Area " Divjaka and Kleçka";

- Spatial Plan for the Natural Monument of Specific Importance "Mirusha Waterfalls";

- Spatial Plan of the National Park "Sharri Mountain";

- Spatial Plan of Special Interest Area "Battle of Koshare";

\section{In the process of drafting:}

- Spatial Plan of Special Interest Area "Hydro Power Plant Zhur";

- Spatial Plan for the National Park "Bjeshket e Nemuna". 
The Assembly of Kosovo has adopted 6 (six) spatial plans so far. Some others are now on the drafting process. In addition to spatial plans it is worth noting the drafting of the Strategy for the Prevention and Regulation of Informal Settlements. Spatial plans at local and central levels designed for 10 years with the option revision every 5 years or in certain cases even more frequently.

Despite the fact that most of them have already been designed and approved by KP (Kosovo Parliament), some plans for particular areas of interest, the main obstacle remains their implementation, more specific case is the Spatial Plan of Area of Special Interest " Divjaka and Kleçka" and "Natural Monument of Specific Importance Mirusha Waterfalls", which have already been designed, but due to the lack of political will and financial cost, is not yet established a body (institution) to manage these areas (parks). Thus, the spatial plan has not any value to the fact that the spatial plan is inapplicable. Therefore, the design of spatial planning is not always a solution to problems, because the latter depends largely on the political and financial support for its implementation. These examples demonstrate how closely are related the projections made by planners with policy-makers or politicians. Both of them must coordinate well with each other in order to have positive developments.

In the above cases, the role of planner is of particular importance, instead of silence, a planer should choose acting.

Skilled spatial planners should have the ability to engage actors at all levels of development (can be found: http://www.unece.org/fileadmin/DAM/hlm/documents/Publications/spatial_planning.e.pdf):

(a) Participation: engaging actors in reciprocal relationships of communications;

(b) Consultation: delivering expert advice for the purpose of drawing conclusions;

(c) Representation: acting on behalf of one or more groups of actors in an effort to represent both ideas and individuals;

(d) Appeal: acting as advocates for collective decision-making and for the improvement of the affected community.

While, at the local level (municipalities) is not so good situation in planning field. Despite that the Planning Law for many times has obligated municipalities to develop their Municipal Development and Urban Development plans; there are still many municipalities that have not developed their spatial plans. According to research conducted in 2010 (Gollopeni, 2010), with its topic: design of municipal and urban development plans in the municipalities of Kosovo, it appears that up to this time have been drawn less than $50 \%$ of municipalities' municipal development plans. According to the survey results, it appears that at the municipal level have been so far made only $36.6 \%$ of municipal development plans, $36.6 \%$ of the municipalities are also in the process of drafting and $26.6 \%$ of the municipalities have either developed, but have not harmonized them with the Law on Spatial Planning, or have not yet started with the drafting of municipal development plan. So, at the municipal level, currently (2010) or $50 \%$ of Kosovo's municipalities have not drafted a municipal development plan. Based on this study, the total number of municipal development plans drafted at local level by 2014, $76 \%$ of Kosovo's municipalities have drafted municipal development plans and have obtained the consent of the relevant Ministry. See graph;

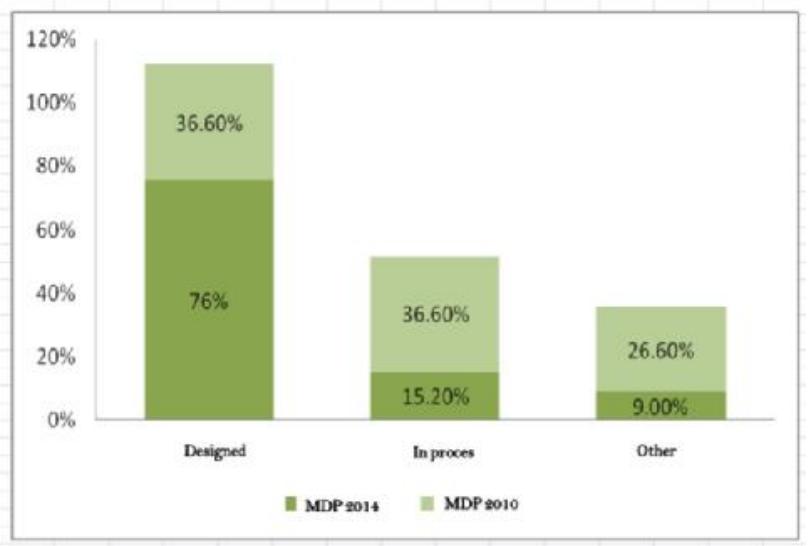

Fig. 3. Draft Municipal Development Plan in 2010 and 2014 (Source: MESP / DSP, analyzed by the autor). 
Until 2014, apart from total of 37 municipalities, $76 \%$ of municipalities have drafted MDP, $15.2 \%$ of the municipalities are in the process of drafting the MDP and $9 \%$ of municipalities have developed but have not received consent from the Ministry and / or are three municipalities in northern Kosovo that still not apply the laws of Kosovo.

Meanwhile, according to the same survey (2010) (Ibd.), less than 50\% of municipalities have drafted Urban Development Plan; $26.6 \%$ of the municipalities are in the process of urban planning design and $26.6 \%$ of other municipalities have not yet started with the drafting of the plan, or have developed it but have not well harmonized with the Law on Spatial Planning.

Despite the entry into force of the Law on Spatial Planning 2003/14, dated 03.07.2003, Article 32 which obliges municipalities within 18 months to draft municipal and urban plans, then the Law no. 03/106 on the Amendment of the Law on Spatial plan and coordinate no. 2003-14, adopted by the Assembly of the Republic of Kosovo in November 10, 2008, article 19, which also requires municipalities to design and approve municipal and urban development plans, one thing still has not happened.

Until 2013, 72\% of Kosovo municipalities have designed an urban development plan, 11.1\% of the municipalities are in the process of drafting the urban development plan and $16 \%$ other or have not harmonized with the Law on Planning or have not yet begun drafting the plan.

Regarding the design of urban regulatory plans which is also the lowest level of spatial planning in Kosovo under the Law 2003/14, a number of them has designed but there is a lack of accurate statistics. Meanwhile, Law No. 04 / L-174 approved last year is not yet complete with administrative instructions and as such has not given results.

Drafting spatial plans with strategic focus, helps balanced territorial development and simultaneously reduce differentiation on social and economic basis as well as environmental negative impacts.

\section{Challenges of the spatial planning}

Apart from 1445 settlements of Kosovo, most rural areas have already municipal development (general) plans. Such spatial plans cover villages superficially but have no specific planning what should be done. As a result of this situation, today, in most rural areas (over 95\%) constructions do not have urban and construction permits. This situation continues to be challenging unless there is no proper policy for rural development, urban regulatory plans for rural areas on the basis of which will be issued a building permit and develop urban and rural housing, etc.. A roughly similar situation exists in some neighborhoods or suburbs of cities in Prishtina such as: Kalabria neighborhood, Mati, etc.. All these unplanned spatial developments in one or another form make the lives of citizens difficult.

One of the main challenges in the central level of spatial planning can be termed: lack of consolidation of relevant institutions (until 2003), the lack of human capacity, lack a serious approach to policymaking and decision-making in the country, and commitment in this area also despite the negative phenomena in space are far more vulnerable. This is due to the fact that, in the programs of political parties competing to take power, spatial planning until the last election (2013), little has been treated or viewed, and the professional aspect is not addressed at all. During the general political elections (2010), during the election campaign in the country, even 1 percent of all political programs, interviews, promises, debates, etc.. leaders and representatives of Kosovo politics, do not mention as a priority the spatial / urban planning field. This clearly shows how the politicians are interested to approach this problem. On the other hand, although spatial plans have been drafted, the challenge is in their implementation on the ground. In most cases, spatial plans serve as decoration work in offices or on shelves covered by dust and thus become irrelevant. Meanwhile, developments in space occur simply "ad hoc", to build an object in space, making decisions on the basis of some laws of different sectors, ignoring spatial and complicated this situation has had an impact on the development of unplanned and also created complications for interested investors and has hampered the lives of citizens in general. Such a situation is not a result of accountability. In developed countries, the responsibilities of relevant institutions should account for the degree of implementation of the spatial plan / s, this issue in transition countries such as Kosovo is still missing. Then, the issue of corruption, nepotism, clans, etc.. are topics 
in themselves which have hampered the implementation of plans, regardless of the level of quality of those plans, etc.

\subsection{Key Challenges (central level);}

- Lack of consolidation of institutions and human capacities: in the early XXI century, the institutions of the country were being consolidated (from the war of 1999); there was a lack of human capacity (experts in the field of planning), and furthermore, it took time to build institutions and human capacity building; on the other hand, after the overall destruction (houses, businesses, infrastructure etc..) from the last war, requirements for construction and reconstruction were great for citizens in the absence of what was said, occurred unplanned spatial constructions.

- Non-implementation of legislation and relevant spatial plans: up to Kosovo's declaration of independence (2008), laws have been implemented at a low scale. In most cases the law implementation was respected by simple people, but not from the elite or political class or socalled "big fishes". Such elite through Balkan-type selfishness was not interested in laws or spatial plans, but in most cases, they are interested only in their individual interest and their clans' ones. As a result of these actions, individually or clan, illegal constructions have been shaped throughout the country especially in urban centers and tourist areas of the country. Likewise, it is also a challenge in itself, the rejection of legislation by Kosovo Serb majority municipalities, especially those north of the country. With the declaration of independence, gradually applies legislation and spatial plans though, still left to be done.

- Lack of monitoring of the implementation of spatial plans and accountability: there is still a lack of monitoring at the country level for the degree of implementation of spatial plans and lack of accountability as well. In developed countries, the issue is regulated by law and in cases of non-implementation of spatial plans by the rate prescribed shall have responsibility. An example of this kind is Latvia, where the lack of enforcement of local spatial planning, forced to resign several mayors.

- Establish database of spatial dates: even today, there is a lack of a database with spatial data at the national level which will enable the design, monitoring and implementation of spatial planning at national and local level.

\subsection{Key Challenges (local level);}

- Lack of proper institutional organization: even today at the municipal level there is a completely unprofessional organization in the field of spatial planning. Most municipalities in Kosovo have no special units for spatial / urban planning, the directorates are even labeled as; directorate for planning, environment, urban planning and cadastre, etc. this form of institutional organization has hampered sharing of tasks and responsibilities. Organization in the field of spatial planning at the local level varies from one to another municipality as example; in Prizren Region from 5 (five) municipalities that make up this region, all municipalities differ on the notion of spatial sectors which make difficult the harmonization and coordination of actions among municipal and sharing of experiences as well;

- Lack of human capacity: in most Kosovo municipalities, in the field of spatial planning hampered them to be able to develop local spatial plans with their own capacities. There is also the lack of staff able to interpret and implement spatial / urban plans.

- Development of plans from private institutions not professional ones: in most Kosovo municipalities, local spatial plans are drafted by private institutions, from which a large number of such institutions are not professional in the field of spatial planning. All this happened for several reasons, such as lack of capacity of municipalities, led them to contract private companies / organizations for the design of spatial plans and in most cases, these private institutions were not focused on the quality of documents through or the quality of citizens life but their benefit as much as possible; 
- Lack of funds: It is well known that transitional period through which Kosovo is undergoing particularly in the early years of this century, many municipalities were destroyed as a result of the recent war ('99) and the requirements of the community were significant, starting from the most basic foods, infrastructure, etc.., thus knowing that the financial cost of spatial design is high, it has become the drafting of such plans not to be a priority;

- Lack of political support: local level was not supported to draft spatial plans. This happened for several reasons such as; policymakers (policy) is more interested to build roads, schools, health facilities, etc.., to be seen by communities and directly influence the acquisition of the electorate (to win votes as much) than the invest large sums of money in developing spatial or strategic plans. The spatial plans designed by the last government mandate coming from another political entity are seen with suspicion by the current government.

In general these are the main challenges or causes of setbacks in the field of spatial planning at central and local level, but it does not end here. Therefore, it is necessary to proceed further with the investigation of challenges or causes in this field, in order to get out of this situation.

\section{Conclusions}

In Kosovo after 1999, spatial and management planning was and remains one of the main challenges for institutions. Although many plans and spatial strategy are drafted, a number of them are considered poor in content but, there are plans which are very good but not or partially implemented. There are also entire neighborhoods built without respecting urban plans and urban norms and standards, such a situation has hampered the lives of citizens. There are also tourist parks which are covered by buildings without plans, from various interest groups which are destroying tourist values though, for such actions recently (2014), the Ministry of Environment and Spatial Planning has taken strict measures for the demolition of illegally constructed buildings though, remains much to be done.

There is also a satisfactory development in the advancement of knowledge in the field of spatial planning by those responsible for drafting of the plans at the central level but there is still a lack of human capacity in the field and also much to be done in advancing knowledge in the specific fields of spatial planning and support from experts.

Spatial plans already drafted at the central level and some of them are in the process however, the main obstacle remains improving the quality of documents and conviction of policy-makers and decisionmakers about the role and importance of their implementation. It is necessary a proper institutional organization to share roles and responsibilities both at local and central level that still is left much to be done.

Over $70 \%$ of Kosovo municipalities have drawn up municipal development plans so far, $20 \%$ of other municipalities are underway while the rest of the municipalities have developed them but have not harmonized with the Law on Spatial Planning. On the other hand, over $70 \%$ of municipalities have designed urban development plans, $11 \%$ of municipalities are in the process of drafting, and $16 \%$ of other municipalities have not yet started with the design of an urban development plan or have developed but have not harmonized with spatial planning law. The main challenge remains the inclusion of rural areas in the field of urban planning, and directions of development will be given through these plans in general and particularly building requirements.

In conclusion, investment in advancing knowledge in the field of spatial planning, raising the quality of spatial planning documents and their implementation, proper institutional organization, etc.., will enable citizens a more comfortable life in space where they live, work, have fun, etc.. 


\section{References}

1. Balaj, N., Gollopeni B., (2012) The effect of pruning on the length of shoots to flowers, flowers and the rose plant architecture in urban gardens, Research 18, Academy of Sciences and Arts of Kosovo.

2. European Conference of Ministers responsible for Regional/Spatial Planning. http://en.wikipedia.org/wiki/Spatial planning.

3. Gollopeni B., (2013) Demographic evolution in Dragash Municipality - development trends, Social Studies Magazine, Vol. 7, No. 2, Albania.

4. Gollopeni, B. (2008) Spatial Planing Proces, Year I. no. 1, Magazine Environment, Prishtina: MESP, pg. 17.

5. Gollopeni, B. (2012) Urbanization and urban planning challenges in Kosovo, European Magazine, no. 6., Prishtina: SOROS, pg. 6-8.

6. Gollopeni, B. (2013a) Shortcomings of spatial/urban planing in Suhareka, Readings in Population, Environment and Spatial Planning, Edited by: K.D. Sharma, H.S. Mangat and K. Surijit Singh, ISPER, Panchkula / INDI, pg. 355-364.

7. Gollopeni, B. (2013b) Urbanization and socio-urban developments in Prishtina in post conflikt period, Proceedings of the 2nd Annual International Conference on Business, Technology and Innovation, Edited by: Edmond Hajrizi, UBT Publication November 2013, pg. 127-133.

8. Hans Leinfelder \& Elke Vanempten "Spatial planning challenges - impressions" http://www.vlm.be/SiteCollectionDocuments/Rurality $\% 20$ near $\% 20$ the $\% 20$ city/rnc_ws leinf elder.pdf

9. http://www.corp.at/archive/CORP2010 222.pdf

10. http://www.uclg.org/sites/default/files/EN 532 mzsapolicypaperwithattachment.pdf

11. Ligji nr. 03/L-106 për Ndryshimin e Ligjit për Planfikim Hapësinor nr. 2003-14, i miratuar në Kuvendin e Republikës së Kosovës me 10 nëntor 2008 dhe ligji për planifikim hapësinor (2013).

12. Public participation in spatial planning process - Year II. no.6.2009, magazine "Environment", Prishtina.

13. Rethinking Spatial Planning, http://siteresources.worldbank.org/INTSOUTHAFRICA/Resources/Todes bladgereedSSno 532008 revised3.pdf

14. Toto, R. \& Çobo, E., "Planifikimi i territorit - Nga ligji në reformë", Tiranë.

15. United Nations, 2008 http://www.unece.org/fileadmin/DAM/hlm/documents/Publications/spatial planning.e.pdf 